\title{
Efektifitas Pemberian Serbuk Jahe (Zingiber Officinale) Terhadap Tingkatan Mual Muntah Pada Ibu Hamil
}

\author{
Finta Isti Kundarti*, Dwi Estuning Rahayu*, Reni Utami \\ *Poltekes Kemenkes Malang Prodi Kebidanan Kediri
}

\begin{abstract}
Nausea and vomiting is a common disorder experienced by $50 \%$ of pregnant women in the first trimester of pregnancy. Efforts to reduce the symptoms can be with food or drinks containing ginger. Ginger has antiemetic and anxiolytic activity. The aim of this study was to determine the effectiveness of ginger to decrease nausea and vomiting in pregnant women 0-16 weeks gestation. The type of research design used is quasy Experimental design. The population in this study were all pregnant women 0-16 weeks gestation who experience nausea and vomiting as many as 24 people in the sub-district Puskesmas Wonorejo Ngadiluwih Kediri. The sample in this study 24 people with using cluster random sampling and systematic sampling. The instrument used was a questionnaire and rhodes INVR. Analysis of the results using Wilcoxon Match Pairs Test test results obtained $\mathrm{p}$ value $0.033<0.05$ then $\mathrm{H} 0$ is rejected so that there are differences decrease nausea and vomiting in pregnant women 0-16 weeks gestation who were not given the ginger and ginger. In conclusion the effective administration of ginger powder to decrease nausea and vomiting in pregnant women aged 0-16 weeks. Suggested for health workers to use ginger as a treatment alternative for reducing nausea and vomiting in pregnant women.
\end{abstract}

Keywords : Giving of ginger powder, decrease of nausea and vomiting, pregnant women

\section{Pendahuluan}

Kehamilan merupakan mata rantai yang bekesinambungan dan terdiri dari ovulasi, migrasi, spermatozoa, ovum, konsepsi, pertumbuhan zigot, nidasi (implantasi) pada uterus, pembentukan plasenta dan tumbuh kembang hasil konsepsi sampai aterm (Manuaba, 2010). Periode antepartum dihitung sejak hari pertama haid terakhir (HPHT) hingga mulainya persalinan. Periode antepartum dibagi menjadi tiga trimester. Trimester pertama secara umum dipertimbangkan berlangsung pada minggu pertama hingga ke-12 (12 minggu), trimester kedua pada minggu ke-13 hingga ke-27 (15 minggu), dan trimester ketiga pada minggu ke-28 hingga ke-40 (13 minggu) (Varney, 2007).

Kehamilan merupakan suatu proses reproduksi yang perlu perawatan khusus, agar dapat berlangsung dengan baik. Resiko kehamilan bersifat dinamis, karena ibu hamil yang pada awalnya normal, secara tiba-tiba dapat berisiko tinggi (repository.usu.ac.id). Usaha untuk mencegah risiko tinggi pada ibu hamil dan mencapai target MDGs adalah pengawasan sebelum lahir (ANC). ANC mempunyai kedudukan yang sangat penting dalam upaya peningkatan kesehatan mental dan fisik kehamilan untuk menghadapi persalinan. Melalui pengawasan kehamilan dapat diketahui berbagai komplikasi ibu yang dapat mempengaruhi kehamilan sehingga dapat diatasi kondisi yang tidak dapat dirujuk ketempat yang lebih lengkap peralatannya sehingga mendapat perawatan yang optimal (Manuaba, 2010).

Mual muntah pada kehamilan merupakan salah satu gejala paling awal, paling umum dan paling menyebabkan stress yang dikaitkan dengan kehamilan selama masa kehamilan. Sebanyak 90\% wanita mengalami beberapa bentuk mual dan muntah yang dapat dimulai dari gejala 
mual ringan yang khas sampai sedang yang dapat sembuh dengan sendirinya dengan/tanpa disertai muntah sampai kondisi berat, yaitu hiperemesis gravidarum. Sekitar 51,4 \% wanita mengalami mual dan 9,2\% wanita mengalami muntah. Keadaan hiperemesis gravidarum yang sangat yang patologis jauh lebih jarang terjadi dibandingkan mual muntah secara logis. Diperkirakan hiperemesis gravidarum yang sangat patologis terjadi dalam 1/500 kehamilan (Tiran,2008).

Mual dan muntah merupakan gangguan yang umum dialami oleh $50 \%$ wanita hamil, dan biasanya paling parah pada trimester I kehamilan. Muntah terjadi ketika pusat muntah dimedula atau zona pemicu kemoreseptor yang terletak di dinding lateral ventrikel ke empat yang terstimulasi. Etiologi muntah belum terbukti, namun menurut perkiraan, kondisi ini dapat disebabkan oleh kadar HCG sirkulasi. Gejala muntah akan semakin parah pada kehamilan mola atau kehamilan kembar. Sebagian wanita hamil gejala tersebut lebih sering muncul pada saat bangun tidur, sehingga kerap sering disebut morning sickness. Sebagian yang lain, gejala mual muntah terus berlanjut sepanjang hari (Holmes, 2011).

Beberapa wanita mengalami mual muntah selama kehamilan mereka. Morning sickness biasanya dimulai pada bulan pertama kehamilan dan berlanjut sampai minggu ke-14 sampai ke-16 (bulan ke-3 atau 4) (Matthews A, 2010). Mual dan muntah selama kehamilan biasanya disebabkan oleh perubahan dalam sistem endokrin yang terjadi selama kehamilan, terutama disebabkan oleh peningkatan fluktuasi kadar HCG (Hormon Chorionic Gonadotropin) khususnya karena periode mual dan muntah gestasional yang paling umum adalah usia 12-16 minggu pertama yang pada saat itu HCG mencapai kadar tertingginya (Tiran, 2008).

Gejala mual muntah dipagi hari atau morning sickness biasa dialami oleh ibu hamil usia dibawah 6 bulan (Bararah,
2011). Kebanyakan wanita yang mengalami gejala mual dan muntah hilang antara minggu ke 16 dan 22 kehamilan. Sebagian kecil wanita 0,3-2 \% akan mengalami kondisi yang lebih serius yang disebut hiperemesis gravidarum yang memerlukan rujukan medis. Bidan dapat menyarankan wanita hamil untuk minum susu sebelum tidur dan mengkonsumsi biskuit kering bersama minuman sebelum bangun tidur dipagi hari, menghindari makanan yang berbumbu atau berbau tajam, dan makan dalam porsi kecil, untuk menjaga kadar gula dalam darah. Selain itu, alat yang memancarkan stimulasi elektrik memulai pergelangan tangan untuk memicu impuls sensori dan neurologis yang mengontrol muntah, akupuntur, obat-obatan herbal dan homeopati juga dapat meminimalkan ketidaknyamanan akibat kondisi tersebut (Holmes, 2011).

Usaha untuk mengurangi gejalanya bisa dengan makanan atau minuman yang mengandung jahe. Jahe yang dapat dikonsumsi oleh ibu hamil bisa dalam berbagai bentuk seperti teh jahe, minuman jahe, permen atau biskuit. Ibu hamil yang mengalami efek samping sakit kepala, mulas atau diare setelah mengkonsumsi jahe sebaiknya dihentikan (Bararah, 2011). Studi awal menunjukkan bahwa jahe mungkin aman dan efektif untuk mual dan muntah semasa kehamilan bila digunakan sesuai dosis yang dianjurkan untuk jangka waktu yang singkat (Mikail, 2012).

Dewasa ini, jahe merupakan bahan ramuan lebih dari $50 \%$ obat-obatan tradisional untuk mengatasi berbagai kondisi sakit seperti mual, kram perut, mabuk kendaraan, demam, gangguan pencernaan dan infeksi. Jahe memiliki kandungan besi dan kalsium yang tinggi (vitahealth, 2008). Sebuah penelitian di Denmark menemukan bahwa jahe tidak menimbulkan masalah ketika diberikan kepada tikus hamil dengan dosis beberapa kali lebih banyak dibandingkan dengan 
yang biasa diminum seorang wanita (Chopra, 2006).

Produk utama tanaman jahe adalah rimpang jahe. Rimpang jahe merupakan sumber minyak jahe yang disebut minyak atsiri. Minyak jahe mengandung minyak terbang (yang mudah menguap) misalnya gingerol (Rukmana, 2011). Senyawa gingerol sebagai kandungan utama dalam rimpang jahe adalah suatu oksidan kuat yang efektif mengatasi radang. Jahe memiliki antiemetik dan kegiatan anxiolytic. Hal ini juga dapat membantu morning sickness. Gingerol dan shogaol dari jahe dapat merangsang aliran air liur, empedu dan sekresi lambung. Jahe juga ditemukan untuk menekan kontraksi lambung dan meningkatkan tonus otot usus dan peristaltik. Konstituen dalam jahe dapat berinteraksi dengan reseptor 5HT-3 dan mungkin sebagian bertanggung jawab menjadi antiemetiknya (Zhion, 2011).

Sebuah survei yang dilakukan oleh Power et al (2001) di Washington DC para wanita menyadari potensi manfaat dari jahe. Ginger tea (seduhan jahe) merupakan teh yang terbuat dari akar jahe yang meranggas dan direndam dalam air mendidih (Tiran, 2008). Ginger tea (seduhan jahe) merupakan cara termudah dalam mengonsumsi jahe untuk mengurangi mual muntah dengan menggunakan irisan jahe yang dicampur dengan air panas dan ditambahkan gula sebagai pemanis (Chopra,2006).

Menurut Power et al (2001) dalam Tiran (2008) mencatat sekitar 51,4\% wanita mengalami mual dan 9,2\% wanita mengalami muntah. Glick dan Dick (1999) beranggapan bahwa sekitar 50\% wanita mengalami gejala mual. Gadsby et al (1993) melaporkan ada 80\% insidensi, yaitu $28 \%$ hanya mengalami gejala mual dan $52 \%$ mengalami mual dan muntah. Tinjauan sistematis dari Jewell dan Young (2000) mengidentifikasi angka mual antara 70 dan $85 \%$ dengan sekitar setengah dari persentase ini mengalami muntah (Tiran,2008).
Mual muntah yang tidak segera tertangani bisa menjadi kasus komplikasi dalam kehamilan yang lebih serius dan berakibat fatal yaitu hiperemesis gravidarum (Tiran, 2008). Prevalensi hiperemesis gravidarum di Indonesia tahun 2008 berjumlah sebanyak 150 orang. Prevalensi hiperemesis gravidarum di Jawa Timur dalam kasus program Jamkesda tahun 2008 sebesar 13 orang kasus, sedangkan di wilayah Puskesmas Cunda Muara Dua Lhok Seumawe (NAD) melaporkan bahwa sekitar $2,4 \%$ wanita yang mengalami mual dan muntah memerlukan hospitalisasi untuk hiperemesis gravidarum.

Berdasarkan data Dinkes Kabupaten Kediri tahun 2012 kasus hiperemesis gravidarum sebanyak 59 orang. Data yang diperoleh peneliti dari Dinas Kesehatan Kabupaten Kediri tahun 2012 didapatkan K1 di Puskesmas Wonorejo sebanyak 656 orang. Studi pendahuluan yang telah dilakukan peneliti di wilayah kerja Puskesmas Wonorejo didapatkan jumlah K1 pada bulan Januari-Maret 2013 sebanyak 155 orang. Jumlah K1 pada bulan Februari 2013 sebanyak 59 orang dari 9 desa. Jumlah kunjungan ibu hamil usia kehamilan 0-16 minggu selama bulan Februari 2013 sebanyak 44 orang dari 9 desa. Jumlah ibu hamil usia kehamilan 016 minggu yang mengalami mual muntah sebanyak 26 orang. Berdasarkan data diatas maka peneliti ingin melakukan penelitian tentang efektifitas pemberian serbuk jahe (Zingiber Officinale) terhadap tingkatan mual muntah pada ibu hamil usia kehamilan 0-16 minggu di Wilayah Kerja Puskesmas Wonorejo Kecamatan Ngadiluwih Kabupaten Kediri.Penelitian ini bertujuan untuk mengetahui efektifitas pemberian serbuk jahe (Zingiber Officinale) terhadap tingkatan mual muntah pada ibu hamil usia kehamilan 016 minggu. 


\section{Metode Penelitian}

Rancangan yang digunakan dalam penelitian ini adalah rancangan penelitian eksperimen semu atau quasy experiment. Populasi ibu hamil usia kehamilan 0-16 minggu yang mengalami mual muntah sebanyak 26 orang. Jumlah sampel peenelitian adalah 24 orang. Sampel dibagi menjadi 2 kelompok yaitu kelompok perlakuan sejumlah 12 orang dan kelompok kontrol sejumlah 12 orang. Teknik sampling yang digunakan adalah multi stage sampling. Teknik sampling pertama yang digunakan adalah cluster sampling dan teknik sampling kedua menggunakan sistematis sampling. Kriteria inklusi dalam penelitian ini adalah : Ibu hamil dengan usia kehamilan 0-16 minggu, Ibu hamil usia kehamilan 016 minggu yang mengalami mual muntah fisiologis (retching dan muntah sebanyak $\leq 6$ kali), Ibu hamil usia kehamilan 0-16 minggu yang tidak pernah mengalami keguguran, Ibu hamil usia kehamilan 0-16 minggu yang mengalami mual muntah bersedia menjadi responden dan bertempat tinggal di wilayah Puskesmas Wonorejo. Kriteria Eksklusi dalam penelitian ini adalah : Ibu hamil yang mempunyai penyakit gangguan mental, Ibu hamil dengan gastritis, hiperemesis gravidarum, kelainan ginjal, kelainan hati, diabetes melitus dan riwayat obstetri jelek (abortus, bekas SC). Penelitian dilakukan di wilayah kerja puskesmas Wonorejo Kecamatan Ngadiluwih Kabupaten Kediri. Penelitian dilakukan pada bulan 28-31 Mei 2013 dan 1-23 Juli 2013. Instrumen penelitian menggunakan timbangan digital dengan merk Mettler Toledo untuk takaran pemberian jahe seberat $250 \mathrm{mg}$ dimasukkan dalam kapsul. Instrumen lain yang digunakan untuk mengukur mual muntah adalah Kuisioner Rhodes INVR. Data dianalisa dengan menggunakan uji Wilcoxon Mann-Whitney U-Test.

\section{Hasil Penelitian Dan Pembahasan Hasil Penelitian}

Hasil pengumpulan data yang dilaksanakan mulai tanggal 28-31 Mei 2013 dan 1-23 Juli 2013 di Wilayah Kerja Puskesmas Wonorejo didapatkan 24 responden yang digunakan sebagai sampel penelitian dan dari hasil pengumpulan data melalui kuesioner didapatkan data sebagai berikut :

Tabel 1 Distribusi Responden Menurut Paritas

\begin{tabular}{ccccc}
\hline Paritas & $\begin{array}{c}\text { Kelompok } \\
\text { perlakuan }\end{array}$ & $\begin{array}{c}\text { Kelompok } \\
\text { kontrol }\end{array}$ & Total & $\begin{array}{c}\text { Total } \\
(\%)\end{array}$ \\
\hline Primipara & 7 & 6 & 13 & 54,17 \\
Multipara & 5 & 6 & 11 & 45,83 \\
\hline Total & 12 & 12 & 24 & 100 \\
\hline
\end{tabular}

Berdasarkan data dari tabel diatas dapat disimpulkan bahwa lebih dari setengah responden yaitu $54,17 \%$ yaitu primipara, sedangkan kurang dari setengah responden yaitu $45,83 \%$ yakni multipara.

Tabel 2 Distribusi Responden Menurut Usia Kehamilan

\begin{tabular}{lcc}
\hline Usia Kehamilan & Frekuensi & Persentase $(\%)$ \\
\hline $1-4$ & 0 & 0 \\
$5-8$ & 12 & 50 \\
$9-12$ & 10 & 41,7 \\
$13-16$ & 2 & 8,3 \\
\hline Total & 24 & 100 \\
\hline
\end{tabular}

Berdasarkan data hasil penelitian didapatkan sebagian besar usia kehamilan ibu yang mengalami mual muntah sebanyak $50 \%$ pada usia kehamilan 5-8 minggu.

Tabel 3 Distribusi Responden Menurut Pendidikan Terakhir

\begin{tabular}{lcc}
\hline Pendidikan Terakhir & Frekuensi & $\begin{array}{c}\text { Persentase } \\
(\%)\end{array}$ \\
\hline SD & 4 & 16,7 \\
SMP & 11 & 45,8 \\
SMA & 8 & 33,3 \\
Perguruan Tinggi & 1 & 4,2 \\
\hline Total & 24 & 100 \\
\hline
\end{tabular}

Berdasarkan data dari tabel diatas dapat disimpulkan bahwa sebagian besar 
responden berpendidikan terakhir SMP $(45,8 \%)$.

Tabel 4 Distribusi Responden Menurut Pekerjaan

\begin{tabular}{lcc}
\hline \multicolumn{1}{c}{ Pekerjaan } & Frekuensi & $\begin{array}{c}\text { Persentase } \\
(\%)\end{array}$ \\
\hline IRT & 13 & 54,17 \\
Swasta/Wiraswasta & 8 & 33,33 \\
Petani & 3 & 12,5 \\
PNS & 0 & 0 \\
\hline Total & 24 & 100 \\
\hline
\end{tabular}

Berdasarkan tabel diatas dapat dijelaskan bahwa sebagian besar dari responden adalah IRT sebanyak 54,17\%.

Tabel 5 Distribusi Responden Menurut Jenis Makanan Selama Hamil

\begin{tabular}{lc}
\hline \multicolumn{1}{c}{ Jenis Makanan } & Frekuensi \\
\hline Makanan berat & 5 \\
Camilan & 13 \\
Buah-buahan & 19 \\
Susu & 6 \\
Berbumbu & 1 \\
Berminyak & 3 \\
\hline Total & 47 \\
\hline
\end{tabular}

Berdasarkan tabel diatas dapat dijelaskan bahwa sebagian besar dari responden mengonsumsi buah-buahan untuk mengurangi gejala mual muntahnya.

Tabel 6 Distribusi Responden menurut frekuensi makanan utama

\begin{tabular}{lcc}
\hline $\begin{array}{l}\text { Frekuensi } \\
\text { Makan Utama }\end{array}$ & Frekuensi & Persentase (\%) \\
\hline 1 & 9 & 37,5 \\
2 & 10 & 41,67 \\
3 & 5 & 20,83 \\
$>3$ & 0 & 0 \\
\hline Total & 24 & 100 \\
\hline
\end{tabular}

Berdasarkan hasil penelitian didapatkan sebagian besar responden frekuensi makan utamanya 2 kali dalam sehari sebanyak 41,67\%.

Hasil dari skor rhodes INVR yang digunakan untuk mengukur derajat mual muntah pada ibu hamil sebelum diberikan serbuk jahe di Wilayah Kerja Puskesmas
Wonorejo didapatkan hasil sebagai berikut:

Tabel 7 Distribusi Frekuensi derajat mual muntah pada ibu hamil usia 0-16 minggu saat sebelum diberikan serbuk jahe di Wilayah Kerja Puskesmas Wonorejo

\begin{tabular}{cccccc}
\hline & & \multicolumn{2}{c}{$\begin{array}{c}\text { kelompok } \\
\text { Norlakuan }\end{array}$} & \multicolumn{2}{c}{$\begin{array}{c}\text { kelompok } \\
\text { kontrol }\end{array}$} \\
\cline { 3 - 6 } & Kriteria & jumlah & $\%$ & jumlah & $\%$ \\
\hline 1 & $\begin{array}{c}\text { mual muntah } \\
\text { ringan } \\
\text { mual muntah } \\
\text { sedang }\end{array}$ & 1 & 8,3 & 3 & 25 \\
3 & $\begin{array}{c}\text { mual muntah } \\
\text { berat }\end{array}$ & 2 & 75 & 8 & 66,7 \\
\hline & Total & 12 & 100,0 & 12 & 100 \\
\hline
\end{tabular}

Data hasil penelitian berdasarkan skor Rhodes INVR

Berdasarkan data yang diperoleh dari hasil penelitian pada kelompok yang diberi serbuk jahe didapatkan sebagian besar responden mengalami mual muntah sedang ada 9 orang $(75 \%)$ dan responden pada kelompok yang tidak diberi serbuk jahe sebagian besar juga mengalami mual muntah sedang 8 orang $(66,7 \%)$.

Hasil dari skor Rhodes INVR yang digunakan untuk mengukur ulang penurunan mual muntah sesudah diberikan serbuk jahe di Wilayah Kerja Puskesmas Wonorejo ditampilkan dalam bentuk tabel dibawah ini :

Tabel 8 Distribusi Frekuensi derajat mual muntah pada ibu hamil usia 0-16 minggu saat sesudah diberikan serbuk jahe di Wilayah Kerja Puskesmas Wonorejo

\begin{tabular}{cccccc}
\hline \multirow{2}{*}{ No } & Kriteria & \multicolumn{2}{c}{$\begin{array}{c}\text { kelompok } \\
\text { perlakuan }\end{array}$} & \multicolumn{2}{c}{$\begin{array}{c}\text { kelompok } \\
\text { kontrol }\end{array}$} \\
\cline { 3 - 6 } & jumlah & $\%$ & jumlah & $\%$ \\
\hline 1 & $\begin{array}{c}\text { mual muntah } \\
\text { ringan } \\
\text { mual muntah } \\
\text { sedang }\end{array}$ & 5 & 41,7 & 2 & 16,7 \\
3 & $\begin{array}{c}\text { mual muntah } \\
\text { berat }\end{array}$ & 0 & 0,0 & 1 & 8,3 \\
\hline \multicolumn{7}{c}{ Total } & 12 & 100,0 & 12 & 100 \\
\hline Data & hasil penelitian & berdasarkan & Skor \\
Rhodes INVR & & & &
\end{tabular}


Berdasarkan data dari tabel diatas setelah pemberian serbuk jahe didapatkan hasil pada kelompok yang diberi serbuk jahe sebagian besar tetap mengalami mual muntah sedang 7 orang $(58,3 \%)$. Hasil dari kelompok yang tidak diberikan serbuk jahe juga mengalami mual muntah sedang 9 orang $(75 \%)$.

Tabel 9 Perbedaan derajat mual muntah pada kelompok diberi serbuk jahe dan kelompok yang tidak diberi serbuk jahe

\begin{tabular}{lcccc}
\hline \multirow{2}{*}{ Kriteria } & \multicolumn{2}{c}{$\begin{array}{c}\text { kelompok } \\
\text { perlakuan }\end{array}$} & \multicolumn{2}{c}{ kelompok kontrol } \\
\cline { 2 - 5 } & sebelum & sesudah & Sebelum & sesudah \\
\hline $\begin{array}{l}\text { mual } \\
\text { muntah } \\
\text { ringan }\end{array}$ & 1 & 5 & 3 & 2 \\
\hline $\begin{array}{l}\text { mual } \\
\text { muntah } \\
\text { sedang }\end{array}$ & 9 & 7 & 8 & 9 \\
\hline $\begin{array}{l}\text { mual } \\
\text { muntah } \\
\text { berat }\end{array}$ & 2 & 0 & 1 & 1 \\
\hline Total & 12 & 12 & 12 & 12 \\
\hline
\end{tabular}

Berdasarkan dari data diatas dapat dijelaskan bahwa pada kelompok yang diberi serbuk jahe terdapat peningkatan mual muntah ringan yang awalnya hanya 1 responden $(8,3 \%)$ menjadi 5 responden $(41,7 \%)$, mual muntah berat yang sebelumnya 2 orang $(16,7 \%)$ menjadi 0 orang $(0 \%)$ karena berkurang menjadi mual muntah sedang. Responden pada kelompok yang tidak diberi serbuk jahe mengalami peningkatan terjadinya mual muntah sedang yang semula 8 orang menjadi 9 orang karena terjadi perubahan mual muntah ringan ke mual muntah sedang oleh 1 responden.

Berdasarkan tabel diatas untuk mengetahui ada tidaknya perbedaan sebelum dan sesudah diberi serbuk jahe diuji dengan menggunakan Wilcoxon Matched Pairs Test yaitu diperoleh $\mathrm{P}$ value $0,33<0,05$ maka $\mathrm{H} 0$ ditolak dan $\mathrm{H} 1$ diterima. Kesimpulannya ada pengaruh pemberian serbuk jahe terhadap penurunan mual muntah pada ibu hamil usia kehamilan 0-16 minggu di Wilayah
Kerja Puskesmas Wonorejo Kecamatan Ngadiluwih Kabupaten Kediri.

\section{Pembahasan}

1. Penurunan derajat mual muntah pada ibu hamil usia 0-16 minggu pada kelompok perlakuan

Berdasarkan data dari tabel diatas dapat dijelaskan bahwa dari 12 responden pada kelompok yang diberi serbuk jahe mengalami penurunan mual mual muntah yakni terjadi peningkatan jumlah responden pada mual muntah ringan sebanyak 1 orang $(8,3 \%)$ menjadi 5 orang $(41,7 \%)$, terjadi penurunan mual muntah sedang dan berat yaitu pada mual muntah sedang dari 9 responden $(75 \%)$ menjadi 7 responden $(58,3 \%)$ dan mual muntah berat dari 2 responden $(16,7 \%)$ menjadi 0 responden.

Mual muntah merupakan keluhan yang begitu sering muncul dan dapat bervariasi dari mual ringan saat bangun tidur hingga muntah terus menerus. Mual muntah lebih sering terjadi pada saat perut kosong biasanya pada pagi hari. Morning sickness biasanya dimulai pada bulan pertama kehamilan dan berlanjut sampai minggu ke-14 sampai ke-16 (Matthews A, 2010). Penyebabnya belum diketahui secara pasti mungkin bisa disebabkan karena kelelahan, berpergian atau beberapa makanan dapat membuat masalah lebih buruk. Mual dalam kehamilan yang terjadi lebih buruk bisa disebabkan karena kehamilan yang ganda atau lebih (Smith, Melanie N, 2012).

Menurut Hollyer et al. (2002) secara psikologis, mual dan muntah selama kehamilan mempengaruhi lebih dari $80 \%$ wanita hamil serta menimbulkan efek yang signifikan terhadap quality of life. Hasil studi yang dilakukan Hollyer et al. (2002) menunjukkan bahwa wanita pekerja dilaporkan mengalami penurunan efisiensi dalam bekerja akibat mual dan muntah, sedangkan 25-66\% wanita hamil lainnya berhenti bekerja akibat gejala mual dan muntah tersebut. Menurut Damayanti (2011) kenyataan bahwa mual 
pagi hari lebih sering terjadi dan cenderung lebih parah pada kehamilan pertama mendukung konsep bahwa faktor fisik dan psikologis juga terlibat. Secara fisik, tubuh yang baru pertama kali mengalami kehamilan belum siap untuk mengalami peningkatan hormon dan perubahan lain dibandingkan tubuh yang sudah pernah hamil. Secara emosional mereka yang hamil untuk pertama kalinya cenderung peka terhadap berbagai kecemasan dan rasa takut yang akan mengganggu lambung.

Sebagian ibu hamil merasakan bahwa mual muntah merupakan hal wajar terjadi saat kehamilan. Sebagian lagi menyatakan bahwa mual muntah merupakan suatu ketidaknyamanan dan mengganggu aktivitasnya sehingga ibu sering beristirahat. Hal ini sejalan dengan teori diatas bahwa terdapat 1 responden yang harus berhenti bekerja dikarenakan mual muntah berat. 2 responden lagi yakni ibu rumah tangga mengalami mual muntah berat sehingga ibu tidak dapat melakukan aktivitas apapun. Mual muntah pada skala berat ini bisa timbul kapan saja tanpa ada faktor pemicu sehingga ibu merasa sangat terganggu. Sedangkan faktor pemicu mual muntah yang paling sering dialami oleh responden ialah reflek gags yakni reflek muntah yang terjadi pada saat ibu menggosok gigi. Refleks gags ini merangsang otak dan saluran gastrointestinal untuk menimbulkan mual muntah. Disarankan pada ibu hamil untuk menghindari menggosok gigi langsung setelah makan agar tidak terjadi mual muntah.

Secara keseluruhan, hasil penelitian dalam studi yang berbeda meresepkan dosis mulai dai $500 \mathrm{mg}$ sampai $2000 \mathrm{mg}$ (chittumma et al., 2009). Karena efeknya pada penurunan mual dan muntah dan karena tidak berbahaya, jahe bisa menjadi alternatif yang baik untuk obat. Mekanisme efek yang mungkin merangsang motilitas saluran pencernaan, mengurangi rangsangan ke Zona reseptor dan menghalangi reaksi pencernaan dan umpan balik mual berikutnya (Robabeh Mohammadbeigi et al., 2011).

Sejalan dengan teori diatas, bahwa mual muntah dapat dikurangi dengan minum jahe sesuai dengan penelitian ini. Hasil penelitian ini menunjukan bahwa terjadi penurunan yang cukup terhadap derajat mual muntah pada kelompok eksperimen. Jahe bisa memperbaiki sistem pencernaan pada ibu hamil sehingga bisa mengurangi mual muntah pada ibu hamil. Faktor lain yang bisa mempengaruhi hasil penelitian ini sehingga bisa mengurangi mual muntah ibu yakni dari jenis makanan yang dikonsumsi ibu. Salah satu responden pada kelompok yang diberi jahe didapatkan terjadi peningkatan mual muntah karena ibu sering mengkonsumsi makanan berminyak. Meskipun ibu mengkonsumsi jahe tetapi jika faktor pemicu mual muntah ibu tidak dihindari maka tetap akan terjadi peningkatan mual muntah.

Hasil penelitian didapatkan sebagian besar ibu memiliki frekuensi makan utama 1-2 kali, frekuensi selingan > 3 kali dan jenis makanan yang dikonsumsi bermacam-macam terdapat buah, camilan, nasi, jenang, susu dan makanan yang berminyak juga berbumbu. Makanan berminyak dan berbumbu dapat mempengaruhi terjadinya mual muntah yakni makanan tersebut banyak mengandung lemak jenuh hampir $90 \%$. Hasil penelitian ini menunjukkan terjadinya kekurangan zat gizi pada ibu hamil disebabkan karena frekuensi makan utamanya kurang dari 3 kali. Zat gizi yang kurang pada ibu hamil akan mempengaruhi proses tumbuh kembang janin. Usaha untuk bisa mengurangi mual muntah ini bisa dengan menghindari faktor pemicu dengan tidak makan makanan berlemak dan berbumbu. Jahe dalam penelitian ini juga berperan karena bisa membantu proses pencernaan menjadi lebih baik sehingga mual muntah bisa berkurang. Kebutuhan nutrisi ibu juga harus lebih diperhatikan dengan mengkonsumsi makanan sedikit-sedikit 
tetapi sering untuk menghindari perut kosong dan membantu proses metabolisme karbohidrat lebih baik.

Faktor pemicu yang lain bisa disebabkan karena kurangnya pengetahuan, informasi dan komunikasi yang buruk dari keluarga sehingga mempengaruhi psikologis ibu dan dapat memperparah gejalanya. Faktor gravida juga mempengaruhi kejadian mual dan muntah. Primigravida bisa terjadi keparahan mual muntah karena tidaknya pengalaman dan kurangnya informasi yang didapat sehingga bisa mempengaruhi psikologisnya. Multigravida bisa lebih mengabaikan keparahan gejala mual muntah karena biasanya akan lebih sibuk dengan anaknya yang lain. Selain itu, multigravida juga sudah mempunyai beberapa pengalaman pada kehamilan lalu dalam mengatasi mual muntah tetapi tidak menutup kemungkinan juga bisa terjadi keparahan jika ibu mengalami stresor yang cukup berat. Komunikasi, informasi dan edukasi tentang ketidaknyamanan dalam kehamilan serta cara mengatasinya harus diberikan kepada para ibu hamil sehingga bisa mengurangi gejala yang dialami oleh ibu hamil dan tidak mengganggu psikologisnya.

2. Penurunan derajat mual muntah pada ibu hamil usia 0-16 minggu pada kelompok kontrol

Berdasarkan data dari tabel diatas dapat dijelaskan bahwa dari 12 responden pada kelompok kontrol dari 3 responden (25\%) yang mengalami mual muntah ringan menjadi 2 responden $(16,7 \%)$. Dari 8 responden $(66,7 \%)$ yang mengalami mual muntah sedang menjadi 9 responden (75\%) dan 1 responden $(8,3 \%)$ yang mengalami mual muntah berat tetap 1 responden $(8,3 \%)$.

Menurut hasil penelitian secara umum didapatkan peningkatan skor INVR tetapi tidak terlalu tinggi karena tetap pada derajat yang sama. Terdapat peningkatan responden yang mengalami mual muntah ringan menjadi sedang sebanyak 2 orang, sedangkan responden yang mengalami mual muntah sedang menjadi ringan terdapat 1 responden. Penurunan mual muntah yang terdapat pada responden no B 11 bisa disebabkan karena bermacammacam faktor. Salah satunya ibu mengurangi rasa mual muntahnya dengan mengkonsumsi camilan sesering mungkin dan mengurangi makanan berat yang dapat merangsang mual muntah. Selain itu ibu juga mengkonsumsi buah-buahan untuk mencegah terjadinya dehidrasi yang dapat memperburuk mual muntah ibu.

Mual dan muntah selama kehamilan biasanya disebabkan oleh perubahan dalam sistem endokrin yang terjadi selama kehamilan, terutama disebabkan oleh tingginya fluktuasi kadar hCG (Human Chorionic Gonadotropin), khususnya karena periode mual atau muntah gestasional yang paling umum adalah pada 12-16 minggu pertama, yang pada saat itu, hCG mencapai kadar tertingginya. Penyebab morning sickness belum diketahui secara pasti kendati sejumlah ide telah dikembangkan. Ide ini mencakup perubahan hormon dalam kehamilan, kadar gula darah yang rendah, lambung yang terlalu penuh, peristaltik yang lambat dan faktor-faktor emosi lain (Varney, 2007). Banyak wanita yang mengalami hiperemesis gravidarum terbukti mengalami peningkatan fungsi tiroid dengan sejumlah kecil mengalami tirotoksikosis gestasional, dengan serum hCG melebihi $200 \mathrm{IU} / \mathrm{ml}$ (Tiran,2008)

Meltzer (2000) yang mengutip hasil penelitian Fischer et al. pada tahun 1990 menjelaskan bahwa terjadi penurunan keparahan mual muntah pada ibu hamil yang diberi jahe dibandingkan ibu hamil yang tidak diberi jahe. Vutyavanich (2001) menambahkan dalam penelitiannya yang berjudul "Ginger for Nausea and Vomiting In Pregnancy: Randomized, Double-masked, placebo-controlled trial". Hasil penelitian ini menunjukkan bahwa pemberian intervensi pada kelompok yang diberikan tablet jahe pada umumnya mengalami penurunan mual muntah 
dibandingkan dengan kelompok yang diberikan plasebo.

Banyak hal yang bisa mempengaruhi penurunan mual muntah dalam kehamilan ini yakni salah satunya yakni makanan. Sebagian besar ibu melakukan kegiatan ngemil sesering mungkin untuk membantu mengurangi gejala mual muntah. Ibu yang suka mengkonsumsi buah-buahan juga bisa membantu mencukupi kebutuhan nutrisi dan membantu mengurangi gejala mual muntah. Beberapa ibu menghindari makanan berbau yang merangsang mual muntah. Ibu yang mual muntah tidak banyak makan karena mereka memiliki pikiran takut terjadi mual muntah sehingga kebutuhan nutrisinya berkurang. Kebutuhan nutrisi yang kurang bisa disebabkan karena kurangnya informasi tentang gizi sehingga sebagian ibu yang mengalami mual muntah memiliki pertambahan berat badan yang minimal dan ada juga yang sampai mengalami penurunan berat badan.

Usaha petugas kesehatan dalam mengurangi mual muntah ini bidan sebaiknya selalu memberikan KIE tentang kebutuhan nutrisi pada ibu hamil dan jenis makanan yang bisa dikonsumsi untuk ibu hamil saat mengalami mual muntah serta pemberian jahe sebagai alternatif pengobatan selain obat kimia karena pengaruh teratogenik pada obat-obatan kimia lebih banyak daripada jahe.

Sesuai dengan penelitian yang telah dilakukan penurunan mual muntah pada kelompok yang tidak diberi jahe tidak terlalu mencolok. faktor psikologis dari ibu juga bisa mempengaruhi penurunan mual muntah. Sehingga sebaiknya dari keluarga bisa memberikan dukungan yang positif agar psikologis ibu tidak terganggu dan tidak merangsang mual muntah. Karena psikologis yang terganggu bisa merangsang nafsu makan ibu sehingga mempengaruhi asam lambungnya bisa menimbulkan mual muntah.

Ibu yang mengalami mual muntah merasakan stress karena membuat nafsu makan ibu turun sehingga ibu tidak bisa memenuhi asupan nutrisi untuk ibu dan dirinya dengan baik. Ibu yang mengalami mual muntah bisa terjadi dehidrasi jika sering mengalami mual muntah. Asupan gizi sangat dibutuhkan oleh ibu untuk memenuhi kebutuhan nutrisinya. Makanan ringan berupa cracker bisa membantu mengurangi mual muntah. Selain itu, buah-buahan juga bisa membantu penurunan mual muntah. Dari penelitian ini sebagian besar ibu juga mengkonsumsi buah-buahan untuk mengurangi mual muntah. Kandungan gizi yang terdapat pada buah-buahan ini dapat membantu kebutuhan nutrisi ibu hamil. Oleh karena itu, usaha tenaga kesehatan dalam mengurangi mual muntah ini bisa dengan jahe yang ditunjang dengan mengurangi faktor pemicu mual muntah. Selain itu, petugas kesehatan dapat memberikan pendidikan kesehatan kepada ibu hamil dalam pemenuhan kebutuhan nutrisi dalam masa kehamilannya khususnya pada ibu hamil yang mengalami mual muntah agar tidak terjadi pertumbuhan dan perkembangan yang terhambat pada bayi sehingga tidak menimbulkan resiko lanjutan pada ibu hamil ditrimester berikutnya dan mencegah terjadinya komplikasi pada ibu dan janin akibat kekurangan nutrisi yang disebabkan mual muntah pada kehamilan.

3. Pengaruh derajat mual muntah pada kelompok eksperimen dan kelompok kontrol di Wilayah Kerja Puskesmas Wonorejo Kecamatan Ngadiluwih Kabupaten Kediri

Berdasarkan tabel diatas untuk mengetahui ada tidaknya perbedaan sebelum dan sesudah diberi serbuk jahe diuji dengan menggunakan Wilcoxon Matched Pairs Test yaitu diperoleh $\mathrm{P}$ value $0,33<0,05$ maka $\mathrm{H} 0$ ditolak dan $\mathrm{H} 1$ diterima. Kesimpulannya ada pengaruh pemberian serbuk jahe terhadap penurunan mual muntah pada ibu hamil usia kehamilan 0-16 minggu di Wilayah Kerja Puskesmas Wonorejo Kecamatan Ngadiluwih Kabupaten Kediri. 
Hasil penelitian yang didapat menyatakan terdapat perbedaan penurunan mual muntah pada ibu hamil usia kehamilan 0-16 minggu yang diberi dan tidak diberi jahe di Wilayah Kerja Puskesmas Wonorejo. Sebagian besar responden pada kelompok yang diberi jahe mengalami penurunan mual muntah yang ditandai dengan penurunan skor Rhodes INVR, terdapat 1 responden yng mengalami peningkatan derajat mual muntah. Sebagian besar responden pada kelompok yang tidak diberi terjadi peningkatan skor rhodes INVR tetapi dalam batas derajat mual muntah yang sama. Terdapat 2 responden yang mengalami peningkatan skor rhodes INVR. Sedangkan 2 responden lagi mengalami derajat mual muntah yang tetap. Tetapi derajat mual muntah pada kedua kelompok tersebut sebagian besar mengalami mual muntah sedang.

Menurut Vikanes (2010) Mual dan muntah adalah komplikasi umum pada awal kehamilan yang terjadi antara 50 sampai $90 \%$ dari wanita hamil, meskipun $28 \%$ dri wanita hanya mengalami mual. Meskipun penyebab mual muntah tidak jelas diketahui, faktor yang mempengaruhi termasuk kehamilan multifetal, disfungsi pencernaan, perubahan hormonal, gangguan dalam sistem vestibular dan infeksi Helicobacter pylori (Robabeh Mohammadbeigi et al.,2011)

Lowdermilk dan Perry (2004) dalam Saswita (2009) faktor fisiologis yang mempengaruhi mual muntah yaitu terjadi pada sistem gastrointestinal dengan gejala kehilangan selera makan, pengurangan sekresi intestinal, gangguan fungsi liver, absorbsi nutrisi terganggu. Beberapa wanita mengalami mual-mual sampai muntah dapat terjadi akibat peningkatan kadar hCG serta gangguan metabolisme karbohidrat. Selain adaptasi fisiologis, dibutuhkan juga adaptasi psikologi karena berbagai stimulus psikologis juga dapat menjadi faktor emosional yang menyebabkan gejala mual dan muntah lebih berat.

Meltzer (2000) yang mengutip hasil penelitian Fischer et al. pada tahun 1990 menjelaskan bahwa terjadi penurunan keparahan mual muntah pada ibu hamil yang diberi jahe dibandingkan ibu hamil yang tidak diberi jahe. Vutyavanich (2001) menambahkan dalam penelitiannya yang berjudul "Ginger for Nausea and Vomiting In Pregnancy: Randomized, Double-masked, placebo-controlled trial". Hasil penelitian ini menunjukkan bahwa pemberian intervensi pada kelompok yang diberikan tablet jahe pada umumnya mengalami penurunan mual muntah dibandingkan dengan kelompok yang diberikan plasebo.

Menurut usia kehamilan, pendidikan terakhir, pekerjaan, frekuensi makanan utama dan selingan responden tidak jauh berbeda dari responden pada kelompok yang diberi jahe dan kelompok yang tidak diberi jahe sehingga wajar jika tidak terdapat perbedaan penurunan mual muntah dari kedua kelompok ini. Selain itu kandungan dari plasebo yang diberikan pada kelompok yang tidak mendapatkan jahe terdapat beberapa vitamin serta zat gizi yang cukup yakni salah satunya terdapat vitamin B yang bisa mempengaruhi penurunan mual muntah ibu meskipun kandungannya tidak terlalu tinggi. Ditunjang dari sisi lain yakni pekerjaan ibu yang sebagian besar responden ini merupakan ibu rumah tangga, wiraswasta dan tani. Mual muntah pada ibu yang bekerja merupakan ketidaknyamanan yang bisa mempengaruhi kualitas kerja ibu. Pekerjaan IRT merupakan pekerjaan yang cukup berat sehingga bisa menimbulkan kondisi fisik ibu berkurang sehingga mempengaruhi pertahanan tubuh menjadi turun dan saat tubuh pada kondisi yang tidak stabil akan terjadi ketidakstabilan juga pada psikologis ibu yang dapat merangsang mual muntah pada ibu. Oleh sebab itu, pada ibu yang bekerja disarankan untuk beristirahat sesering 
mungkin dan mengkondisikan lingkungan pekerjaan menjadi tempat yang nyaman yang tidak membuat ibu merasa stress sehingga dapat mengurangi kejadian mual muntah pada ibu hamil.

Faktor lain yang bisa mempengaruhi penurunan mual muntah dalam kehamilan ini yakni salah satunya yakni makanan. Sebagian besar ibu melakukan kegiatan ngemil sesering mungkin untuk membantu mengurangi gejala mual muntah. Ibu yang suka mengkonsumsi buah-buahan juga bisa membantu mencukupi kebutuhan nutrisi dan membantu mengurangi gejala mual muntah. Beberapa ibu menghindari makanan berbau yang merangsang mual muntah. Ibu yang mual muntah tidak banyak makan karena mereka memiliki pikiran takut terjadi mual muntah sehingga kebutuhan nutrisinya berkurang. Kebutuhan nutrisi yang kurang bisa disebabkan karena kurangnya informasi tentang gizi sehingga sebagian ibu yang mengalami mual muntah memiliki pertambahan berat badan yang minimal dan ada juga yang sampai mengalami penurunan berat badan.

Usaha petugas kesehatan dalam mengurangi mual muntah ini bidan sebaiknya selalu memberikan KIE tentang kebutuhan nutrisi pada ibu hamil dan jenis makanan yang bisa dikonsumsi untuk ibu hamil saat mengalami mual muntah serta pemberian jahe sebagai alternatif pengobatan selain obat kimia karena pengaruh teratogenik pada obat-obatan kimia lebih banyak daripada jahe.

\section{Kesimpulan dan Saran}

Simpulan penelitian adalah : 1). Penurunan mual muntah pada ibu hamil usia kehamilan 0-16 minggu sebelum dan sesudah diberi serbuk jahe (zingiber officinale) sebagian besar mengalami mual muntah sedang sebanyak 58,3\% yakni 7 orang, 2). Penurunan mual muntah pada ibu hamil usia kehamilan 0-16 minggu sebelum dan sesudah yang tidak diberi serbuk jahe (zingiber officinale) sebagian besar mengalami mual muntah sedang sebanyak $75 \%$ yakni 9 orang, 3). Ada perbedaan pengaruh pemberian jahe terhadap penurunan derajat mual muntah pada ibu hamil usia kehamilan 0-16 minggu yang diberi serbuk jahe dan tidak diberi serbuk jahe.

Saran yang diajukan adalah : 1). Peneliti mengharapkan lahan penelitian dapat mempertimbangkan pemberian jahe sebagai terapi nonfarmakologi kepada ibu hamil yang mengalami mual muntah, 2). Hasil penelitian dapat digunakan sebagai bahan bacaan dan dapat menjadi pertimbangan masukan penelitian selanjutnya yang berhubungan dengan jahe ataupun penurunan mual muntah pada ibu hamil, 3). Peneliti berharap untuk dapat melakukan penelitian selanjutnya dengan melakukan penelitian tentang alternatif lain yang dapat mengurangi mual muntah misalnya dengan teknik akupunktur dan perbandingan penurunan mual muntah dengan pemberian vitamin B6 dengan Jahe.

\section{DAFTAR PUSTAKA}

Bararah, V.F. (2011). Jahe Kurangi Gejala Mual Muntah Ibu Hamil di Pagi $\mathrm{Ha}$ ri(http://health.detik.com/read/2011/ 05/14/100514/1639685/jahe-

kurangi-gejala-mual-muntah-ibuhamil-di-pagi-hari) diakses pada tanggal 20 Januari 2013 jam 18.00 WIB

Chopra, D. (2006). Panduan Holistik Kehamilan dan Kelahiran. Bandung: Kaifa.

Damayanti, D.A.R. (2011). Pengaruh pemberian aromaterapi jeruk dengan penurunan rasa mual pada gravida trimester satu Di Puskesmas Kecamatan jagakarsa Jakarta. diakses tanggal 26 Februari 2013 jam 13:57 WIB (http://www.library.upnvj.ac.id/inde x.php? $\mathrm{p}=$ show detail\&id $=6681$ )

Fathia, S. (2011). Aktivitas Antimikroba Ekstrak Jahe (zingiber officinale) 
Terhadap Beberapa Bakteri Patogen. Institut Pertanian Bogor. Diakses tanggal 24 Februari 2013 jam 19:57 WIB. (http://repository.ipb.ac.id/../F11sfa_ BAB\%20II\%Tinjauan\%20Pustaka.) Frequently Asked Questions (FAQ). (2012). Morning Sickness. The American College of Obstetricians and Gynecologists

Gunanegara, Rimonta F, et all. (2009). Perbandingan Efektivitas Kombinasi Ekstrak Jahe dan Piridoksin dengan Piridoksin Saja dalam mengurangi keluhan mual muntah pada wanita hamil. Vol.9. JKM.

Hidayat, A.A.A. (2011). Metode Penelitian Keperawatan dan Teknik Analisis Data. Jakarta: Salemba Medika.

Holmes, D. (2011). Buku Ajar Ilmu Kebidanan. Terj. Eka Anisa Mardella, Pamilih eko Karyuni. Jakarta EGC.

Herbold, N. (2011). Buku Saku Nutrisi. Jakarta : EGC

Indiarti, MT. (2006). Panduan Lengkap Kehamilan, Persalinan Dan Perawatan Bayi. Yogyakarta: Diglossia Media.

Janet Medforth. (2011). Kebidanan Oxford: Dari Bidan Untuk Bidan. Jakarta: EGC.

Kardinan, A. (2008). Meniran Penambah Daya Tahan Tubuh Alami.

Kowalak, J. P. (2011). Buku Ajar Patofisiologi. Alih bahasa Andry hartono. Jakarta : EGC

Kusmiyati, Y. (2009). Perawatan Ibu Hamil. Yogjakarta: Fitramaya.

Leveno, K. J. (2009). Obstetri Williams:Panduan Ringkas. Ed.21. Alih Bahasa Brahm U. Jakarta: EGC Manuaba, I.A.C. (2008). Buku Ajar Patologi Obstetri Untuk Mahasiswa Kebidanan. Jakarta : EGC

(2009). Memahami Kesehatan Reproduksi Wanita. Ed.2. Jakarta : EGC. Penyakit Kandungan dan KB. Jakarta: EGC.

Matthews A, Dowswell T, Haas DM, Doyle M, O'Mathuna DP.(2010).Intervension For Nausea and Vomiting in Early Pregnancy (Review). The Cochrane Collaboration : John Wiley\&Sons,Ltd.

Mayoclinic Staff. (2011). Working during pregnancy: do's and Don'ts.accesed $24^{\text {th }} \quad$ February 2013 (http://www.mayoclinic.com/health/ pregnancy/WL00035)

Mikail, B. (2012). Khasiat Jahe Atasi Rasa Mual (http://health.kompas.com/read/201 2/03/15/14315596/Khasiat.Jahe.Ata si.Rasa.Mual.html) diakses tanggal 20 Janari 2013 jam 18:12 WIB

Notoadmodjo, S. (2010). Metodologi Penelitian Kesehatan. Edisi Rev. Jakarta : Rineka Cipta.

Nursalam. (2008). Konsep dan Penerapan Metodologi Penelitian Ilmu Keperawatan. Jakarta : Salemba Medika. (2011). Konsep dan Penerapan Metodologi Penelitian Ilmu Keperawatan. Jakarta : Salemba Medika.

Penny Simkin, et all. (2007). Kehamilan, Melahirkan \& Bayi: Panduan Lengkap. Jakarta: Arcan.

Prawirohardjo, S. (2008). Ilmu Kebidanan. Ed. 4 Cet-1. Jakarta : Penerbit Bina Pustaka

Rahingtyas, D.K. (2008). Pemanfaatan Jahe (Zingiber Officinale) Sebagai Tablet Isap Untuk Ibu Hamil Dengan Gejala Mual dan Muntah. Program Studi Gizi Masyarakat Dan Sumber Daya Keluarga Fakultas Pertanian.Institut Pertanian Bogor. Diakses tangal 17 Februari 2013 Jam 20:12 WIB.(repository.ipb.ac.id/bitstream/ handle/123456789/A08dkr.pdf?4) 
Riyanto, A. (2011). Aplikasi Metodologi Penelitian Kesehatan. cetakan II. Yoyakarta: Nuha Medika

Repository.usu.ac.id.diakses tanggal 24 Februari 2013 Jam 17:55 WIB (http://repository.usu.ac.id/bitstream /123456789/16572/4/Chapter\%20II. pdf

Repository.usu.ac.id. diakses tanggal 12 Januari 2013 Jam 20:15 WIB (http://repository.usu.ac.id/bitstream /123456789/20037/./Chapter\%20II. pdf)

Robabeh Mohammad beigi, Sholeh Shahgeibi, Nasrin Soufizadeh, Masoumeh Rezaiie dan Fariba Farhadifar.(2011). Membandingkan Efek jahe dan Metoclopramide pada Pengobatan Mual

Kehamilan.Pakistan Journal of Biological Sciences, 14: 817-820. Diakses tanggal 25 Februari 2013 pukul 21:18 WIB (http://scialert.net/fulltext/?doi=pjbs. 2011.817.820\&org=11)

Rukmana, R.(2011). Aneka Olahan Jahe. Yogyakarta: Kanisius

Saswita, Yulia Irvani Dewi, Bayhakki.2009. Efektifitas minuman jahe dalam mengurangi emesis gravidarum pada ibu hamil trimester 1. Jurnal Ners Indonesia. Vol 1, No.2, Maret 2011.

Stright, B. R. (2005). Panduan belajar : keperawatan ibu-bayi baru lahir. Ed.3. Jakarta: EGC

Sugiyono. (2007).Statistika Untuk Penelitian. Bandung: CV ALFABETA

Suprapti, M. Lies. (2007). Aneka Awetan Jahe. Yogjakarta : Kanisius

Syarif, H. (2009). Tesis Pengaruh Terapi Akupresur Terhadap Mual Muntah Akibat Kemoterapi Pada Pasien Kanker; A Randomized Clinical Trial. Program Pasca Sarja Kekhususan Keperawatan Medikal Bedah. FIK UI.

Tekoa L. Raja, CNM, MPH, Patricia Aikins Murphy, CNM, DrPH.(2009). Bukti-Berbasis
Pendekatan untuk Mengelola dan Mual Muntah di Awal Kehamilan. Jurnal Kebidanan \& Kesehatan Wanita. Elsevier Science, Inc.(http://ptintensive.com/images/K ing_and_Murphy_-

_Evidencebased_Approaches_to_M anaging_Nausea_and_Vomiting_in_ Early_Pregnancy.pd)

Tiran, D. (2008). Mual Muntah Dalam Kehamilan. Jakarta : EGC.

. (2007). Mengatasi MualMual Dan Gangguan Lain Selama Kehamilan.terj. Shirley Maya Argasetya. Yogyakarta:Diglosia

Utami, P. (2012). Antibiotik Alami Untuk Mengatasi Aneka Penyakit. Jakarta: AgroMedia Pustaka.

Varney, H. (2007). Buku Ajar Asuhan Kebidanan. Jakarta : EGC

Vitahealth. (2008). Seluk Beluk Food Supplement. Jakarta: Gramedia

Wratsongko, M. (2006). 205 Resep Pencegahan Dan Penyembuhan Penyakit Dengan Gerakan Shalat. Jakarta : Qultum Media.

Zhion. (2011). Ginger-its value in human health-side effects and benefits.Diakses tanggal $19 \quad \mathrm{Feb} \quad 2013$ jam 16:17 WIB (www.zhion.com/herb/Ginger.h tml) 